\title{
THE IMPACT OF FISCAL DECENTRALIZATION ON PUBLIC ADMINISTRATION
}

\author{
Jozef Kubás, ${ }^{1}$ Zuzana Štofková, ${ }^{2} J^{\prime} n$ Mišík ${ }^{3}$
}

\begin{abstract}
The allocating revenue to the individual budgets of self-governments in the Slovak Republic is a highly sophisticated process. Redistribution of resources using fiscal decentralization is an effective instrument through which the government attempts to eliminate subsidizing of municipalities and self-governing regions from the state budget and thus achieve higher stability of the economy. The function of municipalities and higher territorial units is secured by so-called special purpose tax revenues, which do not go into the state budget but directly into the budgets of self-governments. This research contribution focuses on the revenue side of budgets of public administration institutions for the period of the last five concluding budget years. The analysis demonstrates the meaning and importance of tax revenues for the mentioned institutions as well as the expenditure side of the state budget. In this contribution, a comparative study identified the changes that occurred in the individual years of the presented range and subsequently, evaluated fiscal decentralization and its influence on the revenue side of budgets of municipalities.
\end{abstract}

JEL Classification Numbers: H21, H23; DOI: http://dx.doi.org/10.12955/cbup.v5.933

Keywords: Fiscal decentralization, tax, finance, budget.

\section{Introduction}

The state budget provides the funding for public administration in the Slovak Republic, through which the primary functions of the state are financed for the relevant year. The National Council approves the budget through the Act on the State Budget on the Amount of Incomes and Expenditures. In the case of an imbalance between revenue and expenses, it also approves the amount of the deficit. The budget is compiled annually for three budget years, which correspond to calendar years, the first year of which is binding. The budget may also be amended during the year. It takes into consideration incomes that are domestic as well as income resources from the European Union (EU). Benjamin Franklin noted the importance and sovereignty of taxes in his historical sentence: "There are only two certainties in the world taxes and death". It is taxes that are the pillars of revenues, and taxpayers request a functional socio-economic system and the provision of basic needs. A variety of systems and instruments of redistribution of public budgets have been tackled through fiscal decentralization. Fiscal decentralization means independence for authorities of regional administration when deciding on the use of their own revenues, responsibility for the use of public resources, justice when deciding on where to direct public resources and transparency when separating funds according to objective statistical indicators. In this approach, municipalities and self-governing regions can better fulfill their designated tasks and functions as well as meet the requirements of citizens. This research contribution focuses on revenues originating from the Slovak Republic, which comprise the predominant portion of income and a significant portion of tax revenues in the budget.

\section{Methods}

Used methods were analysis, synthesis, comparison, induction, deduction and logical thinking, the main source of information was drawn from the Public Administration Budget .This study focused on the allotment of revenue according to the economic classification in order to identify the importance of tax for revenue of the state budget and regional self-governments. This classification separated the individual revenues into main categories, subsequently, items and sub-items. The main revenues are categorized as follows:

- Tax revenues,

- Non-tax revenues, and

- Grants and transfers.

\section{The Tax System in the Slovak Republic}

The tax regime of the Slovak Republic involves two basic groups of tax revenues: direct and indirect. These taxes make up the major portion of revenue to the state budget. A direct tax is collected directly

\footnotetext{
${ }^{1}$ Faculty of Security Engineering, University of Žilina, Slovakia, Jozef.Kubas@fbi.uniza.sk

${ }^{2}$ Faculty of Operation and Economy of Transport and Communication, University of Žilina, Slovakia,

Zuzana.Stofkova@fpedas.uniza.sk

${ }^{3}$ Faculty of Security Engineering, University of Žilina, Slovakia, Jan.Misik@fbi.uniza.sk
} 
from individual taxpayers and is not transferable to another (Bieliková, 2015). In the fiscal system of the Slovak Republic, income tax has a major position according to law (Act no.595/2003 Coll. on Income Taxes). Direct tax applies to the following:

- incomes of natural persons

- incomes of legal entities

- local taxes

- motor vehicle taxes

With indirect taxes, it is not possible to specifically determine the taxpayer to which the tax relates; such taxes apply to goods and services. The payers, in this case, are manufacturers (producers) while end-consumers are the ones who bear the cost. These taxes include value-added tax (VAT), which according to law (Act no.222/2004 Coll. on Value-Added Tax) is a universal indirect tax and is among the main sources of revenues for the state budget. This type of tax on consumption is characterized as a universal tax in that it all goods and services. The tax applies to all business subjects who have tax obligations (Štofková, 2015). It is indirect in that the end-consumer bears the cost as it is part of the price of the goods or services received, but it is the producer or service provider who delivers the tax to the state budget. Since it is a consumption tax, all public and private spending, including that by a business operator is subject to the tax. Other indirect taxes include specific consumption taxes that are applied independently of VAT. A consumption tax, unlike other taxes, has a fixed amount per unit. Products covered by this tax are in accordance with those in other states of the EU (Kováčiková, 2015). This tax is placed on selected types of goods made domestically and also on imports, but goods brought in from the territory of a third state (outside the EU) in personal luggage, up to a certain value, are exempted. A consumption tax is added onto the sales price and so affects natural persons indirectly, upon the purchase of certain types of goods. As indicated in the Financial Report (2017), in the Slovak Republic, the following items are taxed in this way:

- Alcoholic beverages - spirits, wine, semi-products, and beer;

- Electricity, coal, and natural gas;

- Mineral oil, e.g., motor diesel, motor petrol, lubrication oil, heating oil, liquid petroleum gas (LPG), and others; and

- Tobacco products (cigarettes, cigars, cigarillos, and tobacco) and tobacco raw materials (tobacco leaf, tobacco residue, and tobacco papers).

While the classification of taxes into direct and indirect is important, it is also necessary to designate the territory for taxing and the organization that acts as the administrator of individual taxes. On the basis of this, tax revenues are allocated to the budget of the state, the budgets of higher territorial units (regional government), and the budgets of municipalities. Up until 2014, the tax on motor vehicles belonged to the revenue part of budgets of the higher territorial units. Since 2015, this tax has been revenue of the state budget. For the purpose of increasing revenue to higher territorial units, the state changed the distribution of income taxes from natural persons and thus, boosted the share of income proceeding to self-governing regions. Since 2016, the amended act on budget allocation of tax revenues pertaining to the revenues of a regional self-government has been in force. According to the law (Act no.564/2004 Coll.) tax revenue in the relevant year is divided so that $30.0 \%$ is contributed to the budgets of higher territorial units and $70.0 \%$ to municipalities. Among other revenue for municipalities are local taxes and fees for communal waste and small construction waste, which are defined by the law (Act no.582/2004 Coll. on Local Taxes). These taxes are fixed, modified, lowered, or exempted by municipalities under a generally binding regulation. These include property taxes, dog taxes, the tax on the use of public spaces, accommodation tax, tax from vending-machine sales and non-winning gaming machines, tax on the access and stay of a motor vehicle in the historical part of a town, and tax on core (nuclear) facilities.

\section{Share of Taxes in Incomes of the State Budget}

The state determines what comprises the revenue part of its budget. Fiscal decentralization determines which tax stream will be income and then which of these will be income of the state, higher territorial units, and municipalities. These revenues can be divided according to several criteria: economic classification, organizational classification, and sources of financing (Šoltés, 2016). Figure 1 shows a comparison of the amounts of total income tax revenues into the state budget for a period of five years. 


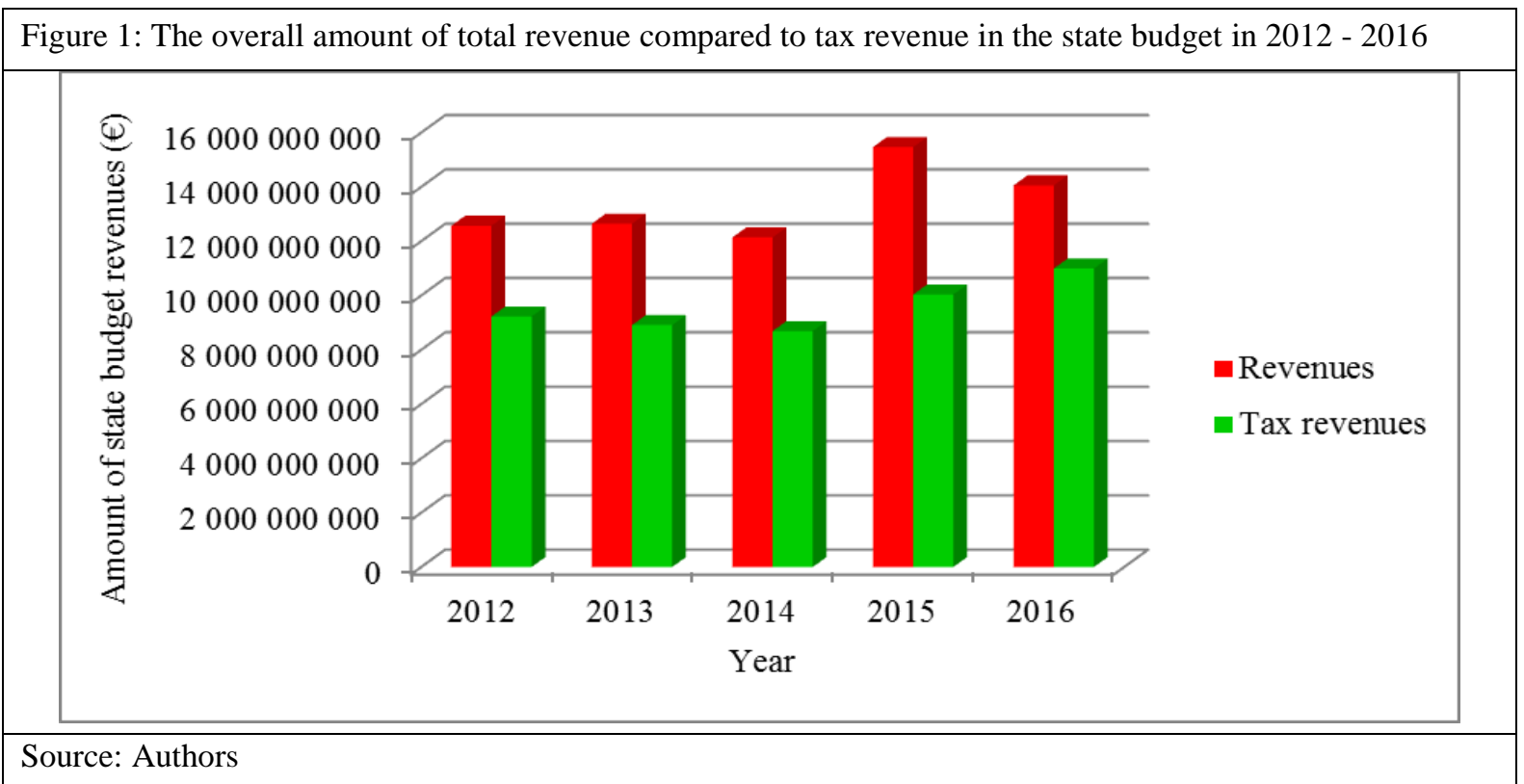

Figure 1 shows the amount of income for the state budget from taxes. For the monitored period, the share of tax revenues was highest in 2016, making up 78.2\% in the given year. The lowest share of tax revenues occurred in 2015 and comprised $64.9 \%$ of total revenue, even though the amount rose yearon-year by about $€ 1,347$ million. This share was influenced by the high proportion of income from EU sources.

Individual tax revenue for the state budget has the following tax sources:

- incomes and capital assets,

- goods and services,

- international trade and transactions, and

- sanctions imposed in tax proceedings and sanctions associated with payments for public services provided by Slovak television and Slovak radio.

\begin{tabular}{|l|l|l|l|l|}
\hline \multicolumn{2}{|c|}{ Figure 2 shows the tax revenue for the individual years for the state budget. } \\
\hline - Sanctions imposed in tax \\
proceedings \\
Source: Authors
\end{tabular}

With the tax structure contributing to the state budget for the monitored periods (Figure 2), the highest share of total tax was from goods and services, which ranged from $72.7 \%$ to $78.7 \%$. The share derived from income tax and tax on capital assets ranged from $20.8 \%$ to $27.4 \%$. Sanctions imposed in tax proceedings and tax from international trade and transactions combined was less than $0.7 \%$.

Regarding fiscal decentralization, taxes were allocated for self-governing regions and municipalities. Since 2015, this has involved the division of revenues from the income tax of natural persons. A 
comparison of total income and tax revenue contributed to the budget of higher territorial units for the period 2012-2016 is shown in Figure 3, and that for the municipalities are shown in Figure 4.

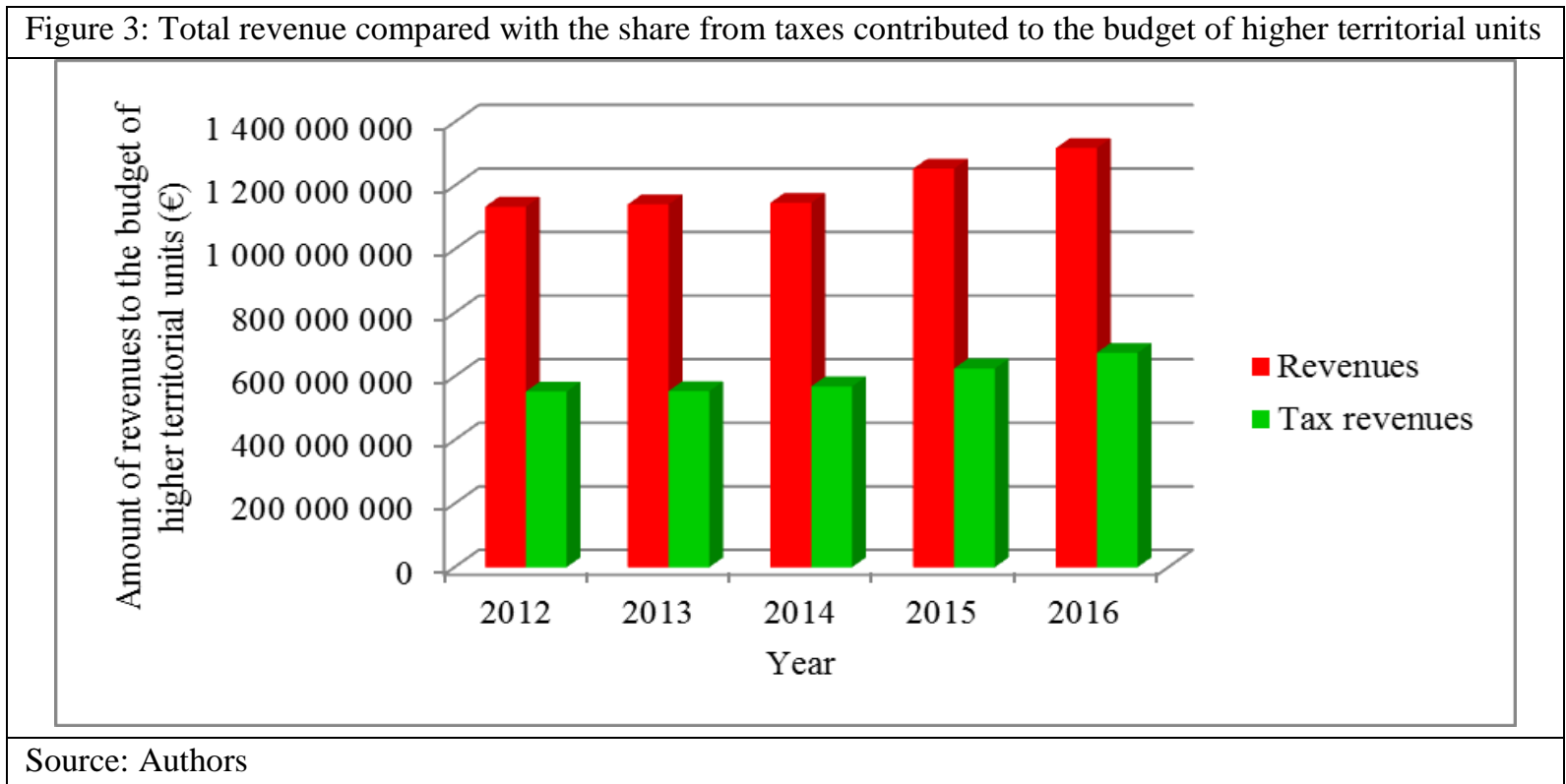

Figure 3 shows an increasing trend of revenue transferring to the budget of self-governing regions. These revenues have grown in direct proportion to tax revenues.

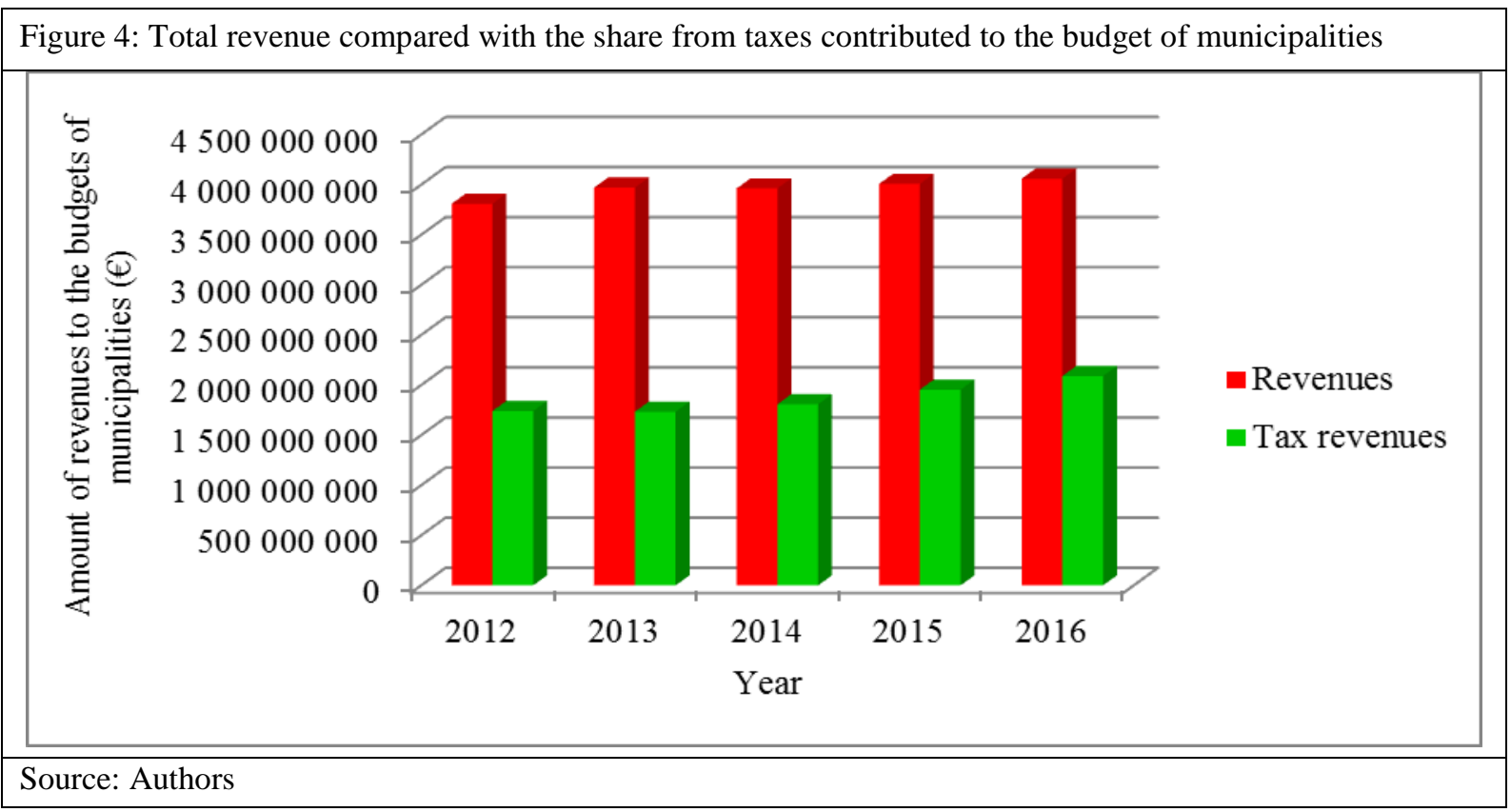

Budget revenues of municipalities are gradually increasing as are revenues from taxes (Figure 4).

\section{Discussion}

This contribution identified the development of revenue of municipalities and self-governing regions after fiscal decentralization in the Slovak Republic. Tax revenues are used in the financing of the state and for financing municipalities and self-governing regions. In 2016, tax in the Slovak Republic comprised as much as $78.2 \%$ of state budget revenues. In 2014, this tax was the highest at $78.7 \%$ and was sourced from tax on goods and services. The remainder consisted of tax revenue and capital assets, which in 2013, at its highest, comprised $27.4 \%$ of total taxes.

It is these taxes that most affect residents and entrepreneurs in the Slovak Republic. When setting the tax burden for these subjects, it is important to proceed with great sensitivity because merely increasing the tax burden may not lead directly to proportionally increased budget yield. The opposite effect may occur, where with higher taxes, the budget revenue streams will trend downwards, as 
entrepreneurs try to avoid paying these taxes in different ways, one of which is shifting the company to a tax haven, where the tax burden is minimal to non-existent. Another method is for people to make payments to one another, or payments directly without any records, and thus, avoid taxation. In countries with high taxes on goods and services, the preference for buying goods and using services of nearby foreign countries may arise.

\section{Conclusion}

Fiscal decentralization, which was preceded by a change of competencies for self-governments and a change of tax laws in the years, 2002 to 2004, has influenced the flow of tax revenue streams for the state budget. Since 2015, the motor vehicle tax has been revenue of the state budget; while in contrast, the total income tax from natural persons has been divided among the regional administrations.

Decentralization has been strengthened by increasing tax revenue streams from natural persons. This endeavor has had a positive effect on the revenue of municipalities and regions, which receive increasing amounts with every year.

\section{Acknowledgment}

This contribution was undertaken as a part of the research projects VEGA 0733/15, VEGA 1/0455/16, VEGA 1/0696/16, IGP 201610 and IGP 201607.

\section{References}

Act no. 222/2004 Coll. Act on Value-Added Tax.

Act no. 564/2004 Coll. Act on Budget Determination of Income Tax Revenues to Regional Self-government, and on amendments and supplements to certain acts.

Act no. 582/2004 Coll. Act on Local Taxes and Fees for Community Waste and Small Construction Waste.

Act no. 595/2003 Coll. Act on Income Tax.

Bieliková, A., Chlebíková. D. (2015). Tax inspection of the tax on personal income in the global economy. In: Globalization and its socio-economic consequences: 15th international scientific conference: proceedings, Rajecke Teplice, Slovak Republic, pp. 33-38. ISBN 978-80-8154-145-2.

Financial Report (2017). [On line]. [ins. 2. 3. 2017.]. Available https://www.financnasprava.sk/sk/obcania/dane/spotrebnedane.

Kovacikova, M., Repková Stofkova, K. (2016). Impact of globalization on access to process businesses management. In: Globalization and its Socio-Economic Consequences: 16th International Scientific Conference: proceedings, Rajecke Teplice, Slovakia, pp. 1022-1030. ISBN 978-80-8154-191-9.

Public administration budget. [On line]. [ins. 10. 3. 2017.]. Available http://www.rozpocet.sk/app/ homepage/rozpoce tVCislach/rozpocetVerejnejSpravy/.

Štofková J., Repková Štofková, K., Kaštánek, P. (2015). Finance. Bratislava: DOLIS, 152 p. ISBN 978-80-8181-005-3.

Šoltés, V., Repková Štofková, K. (2016) The impact of business environment on regional disparities. - Prague: 187-191 pp. ISBN 978-80-88042-05-1. 